\title{
Digital/Cashless Economy: The Changing Landscape of India
}

\author{
Shivangee Kumar \\ Chief Manager, State Bank of India, Navi Mumbai, India \\ *Corresponding author: shivangeekumar86@gmail.com
}

\begin{abstract}
Digital/ Cashless banking has become talk of the town recently. People are opting for digital payments using mobile applications/wallets instead of cash and GOI/RBI is also promoting it through various schemes and incentivisation. This mode of payments has actually changed the dynamics of consumer and corporate relationships with their banks. Now, instead of taking out cash from our wallets, we open our mobile wallets to make payments or transfer money to someone. We do not wait for the bank branch to open and stand in long queues for getting our cash deposited in account neither we wait to withdraw cash. Likewise, we do not count cash at shopping counters and make the payment in a flash using our debit/ credit card. All this is possible because of the innovation in IT and its optimum utilization by our banks. The present paper will give an idea about what is this buzz word "Digital/ Cashless Banking" and how has it changed the banking relationships these days.
\end{abstract}

Keywords: BHIM, Cashless, Demonetization, Digital banking, Digitalization, Mobile banking, POS, UPI, USSD, Wallets.

\section{Introduction}

Going to a bank branch and standing in long queues just to deposit cash in account or withdraw money is a thing of past now. The man of today has no time to wait nor is he dependent on his bank only for day-to-day activities. Today, we have multiple options to do a single transaction and that too sitting comfortably at our home/ watching a movie or even while travelling. We just have to take out mobile, open an app and just do the transaction. So fast and hassle free...right!!! This freedom to do anytime anywhere banking or shopping or paying bills, etc. is the result of IT innovations and advancements. Today, we can buy clothes/ electronics/ home furnishings and even groceries/ medicines online without any involvement of cash and without time constraint.

Behind all this is the Internet and its service providers. Today, the traditional branch banking has seen a paradigm shift towards online / internet driven banking. People do not need rather avoid to visit their bank branches for getting account opened or getting ATM card issued or transferring money to someone or even availing loan from banks.

All this has become available to us anywhere and anytime in the form of different channels made available in India and even worldwide. Few such names are ATM, POS, Internet Banking, Mobile Banking Applications, Debit/Credit Cards, Mobile Wallets, UPI, Bitcoins, etc. Banks are also asking their customers to make optimum use of these facilities available to them and make them aware of the facilities available in form of different mobile applications with pre-approved offers for loans or cashback offers on utility bill payments.

In Indian scenario, though these channels are not so new, the real thrust to their use was facilitated only during demonetization announced by the current Central Government in November 2016. When the Specified Bank Notes (SBN) were banned from further circulation in Indian economy, people were forcibly migrated to use Internet Banking and different Mobile wallets like Paytm, SBI Buddy, Mobikwik, etc. This led to a revolution in the field of Digital Banking, which further led to development of various mobile applications on different platforms like Unified Payment Interface (UPI).

Usage of wallets reached to such an extent that even street vendors and other hawkers started to accept payment through them. Now we need not worry if we do not have cash in our wallets as the payment can be done using our mobile. What can be easier than this... to just swipe the card and the payment done in flash of seconds. All banks and other fin-techs are focusing to move toward digital era. Currently, there are many players in market which facilitate banking services in an easy and fast manner which makes it easier and hassle free for the customers with anywhere anytime availability. This is the Digital Revolution.

In order to increase awareness about digitalization, RBI constituted a committee on "Deepening of Digital Payments", which constituted of a Chairman and 4 other members. Mr. Nandan Nilekani chaired the committee.

The committee had been given responsibilities for boosting Digital Revolution like:

1. Evaluate the existing position of digital payments in India.

2. Try to understand the hiccups and fix them for enabling digital literacy.

3. Measure the levels of digitalization in Financial Inclusion.

4. Recommend measures to boost digitalization across all spheres of economy.

The committee submitted its final report on 17th May, 2019 and its recommendations have been summed up as mentioned below: 
1) Enhanced targets for digital payments: The Committee has established several targets to increase digital transactions in coming 3 year, such as (i) 10 times growth in digital transactions from 22.4 to 220 (ii) Increasing the value of digital transactions as a $\%$ of GDP from $769 \%$ currently to $1500 \%$ and (iii) Expanding the number of digital payment users.

2) Boosting digital payments through POS machines: MDR is the fee paid by merchants to banks for debit/ credit card transactions. It was suggested to have subsidised rate for MDR and cut interchange fee on card payments by 15 basis points to boost digital payments across the country.

3) Digital payments for government procurements: It say that all payments for government procurements/ DBTs, pensions, etc. must be made via digital mode only.

4) Grievance redressal mechanism for digital payments: It said that a dedicated grievance redressal system must be in place to handle technical and other failures in digital transactions.

5) Development of financial inclusion index: To compare different areas across the country with respect to Digital Literacy, a FI Index must be created based on some parameters like number of people having bank accounts, number of people having mobile banking facilities, women population having bank accounts, etc.

6) Liberalised KYC process for customers: It recommended to relax the KYC process so that more and more people can be brought under Digital Umbrella.

\section{Steps Adopted by GOI to Encourage Digital Banking}

In order to transform India into a cashless economy, Govt. of India has initiated the programme named Digital India with a vision to have a Faceless, Paperless and Cashless economy.

The DI programme envisages to provide to all citizens of India a smooth, affordable, transparent, easy, user friendly, hassle free and secured payment facility.

Presently, we have several channels/ modes of transactions which enable us to improve the digital initiative in the country and help us build a cash-less economy. Few to be named are:

\begin{tabular}{|l|l|}
\hline \multicolumn{1}{|c|}{ Channels } & \multicolumn{1}{|c|}{ Features } \\
\hline Internet Banking- & $\begin{array}{l}\text { Facility available for customers to carry out } \\
\text { financial as well as non-financial transactions } \\
\text { anytime and anywhere. }\end{array}$ \\
\hline Mostic Money like & $\begin{array}{l}\text { Mobile apps offered by different banks which } \\
\text { offer the convenience of doing any kind of } \\
\text { transaction anytime and anywhere }\end{array}$ \\
\hline Credit/ Debit Cards- & $\begin{array}{l}\text { Credit/ debit cards allow customers to carry out } \\
\text { transaction on internet or on POS without any } \\
\text { need to carry hard cash. }\end{array}$ \\
\hline
\end{tabular}

\begin{tabular}{|l|l|}
\hline POS machines- & $\begin{array}{l}\text { Point of sale machines enable swiping of } \\
\text { Debit/ Credit cards and hassle-free transaction } \\
\text { for the customers. }\end{array}$ \\
\hline AEPS- & $\begin{array}{l}\text { Customer can do Aadhar enabled transactions } \\
\text { at POS present with Business Correspondent } \\
\text { (BC). It expands the digitalization to Rural } \\
\text { India }\end{array}$ \\
\hline $\begin{array}{l}\text { UPI based applications } \\
\text { like BHIM, BHIM }\end{array}$ & $\begin{array}{l}\text { Unified Payment Interface is a platform that } \\
\text { enables interoperability between different } \\
\text { banks for various transactions }\end{array}$ \\
\hline $\begin{array}{l}\text { Micro ATMs- } \\
\text { A handheld device present with BCs of the } \\
\text { banks which help the customers carry out their } \\
\text { transactions with help of Aadhar. }\end{array}$ \\
\hline $\begin{array}{l}\text { USSD- } \\
\text { (c( }\end{array}$ & $\begin{array}{l}\text { Unstructured Supplementary Service Data } \\
\text { (*99\#) is a facility to carry out transactions } \\
\text { through mobile without any internet facility }\end{array}$ \\
\hline
\end{tabular}

These are the several modes of transactions which help us to transfer funds to someone or recharge mobile/ TV or even open a Fixed deposit account without visiting the branch.

\section{Mobile Applications Available by Different Banks}

1. ICICI Bank iMobile App: Features available are manage deposit accounts and transactions, funds transfer, cheque payments, accounts transfer, bill payments, recharges, credit cards and loans, investments, insurance purchase, ticket booking, forex travel card, etc.

2. HDFC Bank Mobile banking App: Features available are bill payments, recharges, manage deposit accounts, open fixed deposit, forex travel card, manage debit cards, etc.

3. HDFC Loan Assist provides $24 * 7$ assistance to manage loan accounts, check the status of EMI paid, interest rate changes, etc. This service is free of charge.

4. Payzapp: This app from HDFC bank helps in carrying out various transactions like travel bookings, mobile or TV recharge, grocery shopping and ticket booking for movies and earn cashback too.

5. YONO (You Only Need One) by SBI: Features available are open account digitally without vising branch, cash withdrawal, manage debit/ credit card, utility bill payments, tax payments, loan facility, pre-approved loan offers, open fixed deposits, etc.

6. Kotak Bank Mobile App: Features available like open and manage accounts, funds transfer, manage debit/credit cards, online shopping, open fixed deposit

7. BHIM Kotakpay: Using UPI interface, different financial transactions can be carried out.

8. Kotak AIA: Kotak Life Insurance premiums can be paid here and other related transactions can be done in a fast and easy manner.

9. Kotak Mutual Fund: One can manage his mutual fund accounts and carry out related transactions through this app.

\section{MeiTY Initiatives for Promoting Digital Literacy Across Country}

MeiTY has developed a dashboard named "Digidhan 
Dashboard" to effectively monitor the coverage of digital transactions across the country. Data for this dashboard is provided by different banks and is updated on a regular basis. Based on the insights from this dashboard, decisions are taken for providing or enhancing infrastructure for enabling digitalization across different stakeholders.

As on 30.06.2020, following insights from the dashboard have been derived:

1. Total accounts with Aadhar seeded - \# $112.51 \mathrm{Cr}$

2. Total digital transactions during FY 2019-20- \# 4,572 Crore

3. Total Physical \& Mobile POS deployed- \# 57,87,878

4. Total BHIM Aadhaar Pay POS deployed- \# 11,27,799

5. Total accounts with Mobile seeded- \# $108.17 \mathrm{Cr}$

MeiTY has been delegated with the task to promote and strengthen digital transactions and payments across the country. To make this happen, several initiatives have been taken up by the ministry. To sum up, few of them are illustrated below:

1) Conducting training and workshops on digital payments awareness with several Ministries like Ministry of Power, Agriculture, Panchayati Raj, Department of Post, etc.

2) Sharing information for advertising of digital payments to increase awareness.

3) Development of Digidhan dashboard to effectively monitor the coverage of digitalization across the country.

4) Announcement of promotional scheme for transactions through BHIM Aadhaar

5) Offering of cashback to merchants for transactions through BHIM interface.

6) Offering of bonus on referrals for Individuals

7) Digital Jagriti: A service centre with an aim to make people aware of the digital modes of transactions and promoting acceptance of digital payments by one and all.

8) DigiShala: It is a TV channel available on DD Free Dish which aims to educate people in rural India who have no access to banking facilities. Its vision is to spread digitalization to the remotest part of India so that we can actually become a cashless and paperless economy.

\section{Benefits of Digital Banking}

Digital Banking is beneficial to Banks as well as customers in several ways.

Benefits to banks:

1. Reduces Operational costs

2. Reduces workload on staff

3. Increases customer satisfaction and delight

4. Enhances customer experience

5. Helps banks improve image in market

6. No fear for fake currencies
Benefits to customers:

1. Fast and hassle-free transactions

2. $24 \times 7$ availability

3. No need to wait in long queues in Banks

4. Small gains through cashbacks and other offers/ discounts

5. Secured and reduced risk of losing cash

6. Spends can be easily tracked and contained

7. No fear for fake currencies

8. Anywhere and anytime transactions

\section{Disadvantages of Digital Banking}

Similar to two sides of a coin, there are few hitches in Digital banking like:

1. Robust Infrastructure is required for enabling digital transactions.

2. Increased risk of losing money through hacking passwords, etc. or other frauds.

3. One may end up spending more than what is actually required.

4. Needs Internet facility and smart phones for executing digital transactions.

5. Online transactions are levied with some convenience fee or charges unlike cash transactions.

6. Dependency on better connectivity.

Further, to protect the customer from digital frauds, RBI has issued a circular,

RBI/2018-19/101/DPSS.CO.PD.No.1417/02.14.006/2018-

19 dated 04.01.2019, according to which:

1. Customers must register for SMS alerts

2. SMS alerts should be sent for any payment transaction

3. Customers should be advised to apprise the bank of any unauthorised transaction in his/ her account at the earliest.

4. Banks should provide $24 * 7$ facility to report unauthorised transactions and complaint portal should also be made available on all access points for customers.

5. If the customer informs bank of any unauthorised txn in the account within 3 days of occurrence, customer is not liable for any loss.

\section{Conclusion}

To conclude, I would say that we are living in digital era and there is much more to see. Technology is surprising us every day with something new. Our next generation is going to be the Tech generation. Everyone demands services at doorstep and Banks have to work towards achieving these milestones to survive in a cut-throat competitive world where new players like Fintechs, Payments Banks, Small Finance Banks have also come into existence. With the advent of such peers, it is a cutthroat competition for all the players in market to offer affordable and hassle- free services to its customers. Those will sustain whom the customers want and support. We need to 
Volume-3, Issue-9, September-2020 journals.resaim.com/ijresm | ISSN (Online): 2581-5792 | RESAIM Publishing

understand and envisage that cashless banking is the future of Indian economy and we must strive to achieve this.

\section{References}

[1] www.rbi.org.in

[2] https://www.enterpriseedges.com/role-of-digital-banking-india

[3] https://www.digitalindia.gov.in/

[4] https://www.meity.gov.in/digidhan,
[5] https://www.wishfin.com/banks/mobile-banking-apps-of-top-banks/

[6] http://cashlessindia.gov.in/ussd.html

[7] https://digipay.gov.in/dashboard

[8] Athifa Mymoon, "Cashless Economy (Digital India)."

[9] Neha Kaushik, "Cashless Economy: A key to Digital Proliferation in Indian Banks," IJCRT Conference on Recent Innovations in Emerging Technology \& Science, April 6-7, 2018.

[10] Jyoti Dashora, "Digital India: Limitations \& Opportunities," IJARIIE, vol. 3, no. 3, 2017. 